\title{
Pseudohyperkalemia and pseudohyperphosphatemia after splenectomy in hepatosplenic schistosomiasis mansoni
}

\author{
Pseudohipercalemia e pseudohiperfosfatemia após esplenectomia \\ em paciente com esquistossomose mansônica hepatoesplênica
}

\section{Dear Editor:}

Pseudohyperkalemia has been described in patients with thrombocytosis caused by a variety of diseases ${ }^{15}$. To our knowledge, this is the first report of a patient with hepatosplenic schistosomiasis who developed extreme thrombocythemia after splenectomy ${ }^{2}{ }^{3}$ and in whom in vitro platelet clotting caused pseudohyperkalemia and pseudohyperphosphatemia.

A 42-year-old male patient with hepatosplenic schistosomiasis was admitted to hospital in January 2007, with bleeding esophageal varices and was operated on for portal hypertension (splenectomy + portal variceal disconnection + suturing of varices). He was discharged from hospital 15 days after surgery in good clinical condition. One year later he came to our hospital reporting recurrent episodes of dizziness, syncope and right hemiparesis and, in his hometown, he was treated for epilepsy with anticonvulsants, without improvement. After admission he was found to have nephrotic syndrome (12g of protein in the urine/day). The mean platelet count was 2.7 million measured in 3 different occasions. The serum level of potassium was $7.0 \mathrm{mmol} / \mathrm{L}$ (normal range: $3.5-5.1 \mathrm{mmol} / \mathrm{L}$ ) and the serum level of phosphorus was $8.9 \mathrm{mg} / \mathrm{dl}$ (normal range: $2.5-4.9 \mathrm{mg} / \mathrm{dl}$ ). There were no clinical signs or symptoms of electrolyte imbalances, nor electrocardiograph alterations. No clinical response was obtained with the routine treatment for hyperkalemia (exchange resin and intravenous glucose + insulin). Hemodialysis sessions were mistakenly used to correct the electrolyte imbalance. After pseudohyperkalemia was suspected, potassium and phosphorus were measured in plasma (with heparin), and both were found to be within the normal range.

Post-splenectomy thrombocytosis is an important cause of pseudohyperkalemia, and this is, in fact, an incorrect laboratory result because it appears in patients with thrombocytosis, only when the electrolytes are measured in blood collected in tubes without anticoagulants.
Potassium release from platelets is a universal phenomenon during coagulation, and the more platelets present, the more potassium will be released. In cases of extreme thrombocythemia, it becomes clinically significant to cause a spurious serum hyperkalemia. In normal subjects, the median serum potassium concentration is $0.2 \mathrm{mmol} / \mathrm{L}$ higher than the plasma potassium concentration. A diagnosis of pseudohyperkalemia can be confirmed when the difference is more than $0.4 \mathrm{mmol} / \mathrm{L}$ in the presence of an elevated potassium level5.

In our patient, the occurrence of glomerulonephritis ${ }^{2}$ was a confounding factor in the diagnosis of real or pseudohyperkalemia and pseudohyperphosphatemia ${ }^{4}$. This patient was submitted to hemodialysis based on a mistaken diagnosis of hyperkalemia and hyperphosphatemia which brings a definite threat to life. Both clinicians and surgeons need to be aware of this phenomenon in order to avoid unwanted and potentially detrimental treatment including hemodialysis. Also, to our knowledge, this is the first description of pseudohyperphosphathemia ${ }^{4}$ in patients with thrombocytosis. This case reported here, nicely demonstrates the value of using plasma rather than serum potassium concentration as a clinical measure of electrolytes.

\section{REFERENCES}

1. Johnson CM, Hughes KM. Pseudohyperkalemia secondary to post-splenectomy thrombocytosis. The American Surgeon 67: 168-70, 2001.

2. Lambertucci JR. Schistosoma mansoni: pathological and clinical aspects. In: Jordan P, Webbe G (eds) Human Schistosomiasis, $1^{\text {rst }}$ edition, Cab International, Wallingford, UK p. 195-225, 1993.

3. Lambertucci JR, Serufo JC, Gerspacher-Lara R, Rayes AA, Teixeira R, Nobre V, Antunes CM. Schistosoma mansoni: assessment of morbidity before and after control. Acta Tropica 77: 101-109, 2000.

4. Larner AJ. Pseudohyperphosphatemia. Clinical Biochemistry 28: 391-393, 1995.

5. Sevastos N, Theodossiades G, Archimandritis J. Pseudohyperkalemia in serum: a new insight into an old phenomenon. Clinical Medicine and Research 6: 30-32, 2008.

\section{José Roberto Lambertucci ${ }^{1}$, Alba Otoni ${ }^{1}$ and Valério Ladeira Rodrigues ${ }^{2}$}

\footnotetext{
1. Curso de Pós-Graduação em Ciências da Saúde: Infectologia e Medicina Tropical, Faculdade de Medicina, Universidade Federal de Minas Gerais, Belo Horizonte, MG. 2. Departamento de Nefrologia, Faculdade de Medicina, Universidade Federal de Minas Gerais, Belo Horizonte, MG.

Address to: Dr. José Roberto Lambertucci. Faculdade de Medicina/UFMG. Av. Alfredo Balena 190/sala 169, 30130-100 Belo Horizonte, MG, Brasil.

Telefax: $55313248-9820$

e-mail: lamber@uai.com.br

Recebido para publicação em 12/11/2008

Aceito em 14/11/2007
} 